\title{
Influence of Soil Deformation Caused by Mining on Sewage Pipelines Built Using The Pipe Jacking Method
}

https://doi.org/10.2478/sgem-2018-0010

received January 1, 2018; accepted April 19, 2018.

\begin{abstract}
This paper discusses the issues associated with the influence of underground mining operations on sewage pipelines built using the pipe jacking method. At present, to build sewage pipelines, especially in urban areas and deep embedment, trenchless technologies are employed. Mainly in these technologies, pipes are jacked into a bored tunnel using hydraulic jacks. These methods are also applied in mining areas.
\end{abstract}

The aim of this paper is to analyse the influence of ground deformation, caused by mining operations, on sewage pipelines built using the pipe jacking method. The type of pipelines discussed here is built with butted sections, which cannot compensate the influences of mining operations in pipe joints if horizontal compression occurs in the near-surface layer of soil. Pipelines embedded in trenches in the mining areas are secured against the influence of mining operations with expansion joints, which compensate for ground deformation. Hence, in the analysis of the influence of soil deformation caused by mining on sewage pipelines built using jacking method, special attention was paid to the performance of pipe joints. Pipelines of the type are subjected to additional loads and displacements, caused by soil deformations like horizontal strains, horizontal soil displacements and surface curvatures. We propose a way to consider the influence of mining operations on sewage pipelines built using the pipe jacking method.

Keywords: sewage pipeline; pipe jacking method; mining area.

\footnotetext{
*Corresponding author: Piotr Kalisz, Magdalena Zięba, Central Mining Institute, Department of Surface and Structures Protection, Plac Gwarków 1, 40-166 Katowice, Poland, E-mail: pkalisz@gig.eu, mzieba@gig.eu
}

\section{Introduction}

Trenchless technologies are employed for building sewage pipelines mainly in urban areas and when they have to be embedded deep underground. The technologies offer many advantages such as minimal earthworks and requiring limited space for their construction $[7,9,19]$. Trenchless technologies are also applied to build sewage pipelines in mining areas.

The aim of this paper is to analyse the influence of ground deformation caused by mining on sewage pipelines built using the pipe jacking method. In mining areas, such pipelines, unlike pipelines assembled in trenches, are built of butted segments, which cannot compensate for deformations of ground in pipe joints. Hence, when analysing the influence of soil deformations caused by mining on sewage pipelines built using the pipe jacking method, special attention was paid to the performance of pipe joints. In mining areas, these pipelines are subjected to additional loads and displacements, caused mainly by the influence of horizontal strains, horizontal displacements and surface curvatures. We also propose a method to consider the influence of ground deformations caused by mining on sewage pipelines built using the pipe jacking method.

\section{Characteristics of Sewage Pipelines Built Using Pipe Jacking Method}

Building a sewage pipeline using the pipe jacking method is employed in trenchless technologies: hydraulic jacking and microtunelling. In the microtunelling technique, pipeline sections are jacked one by one from the launch shaft into the tunnel, bored with the cutting head, forming even a few-hundred-meter-long section leading to the reception shaft (Fig. 1). The launch shaft has to accommodate all 


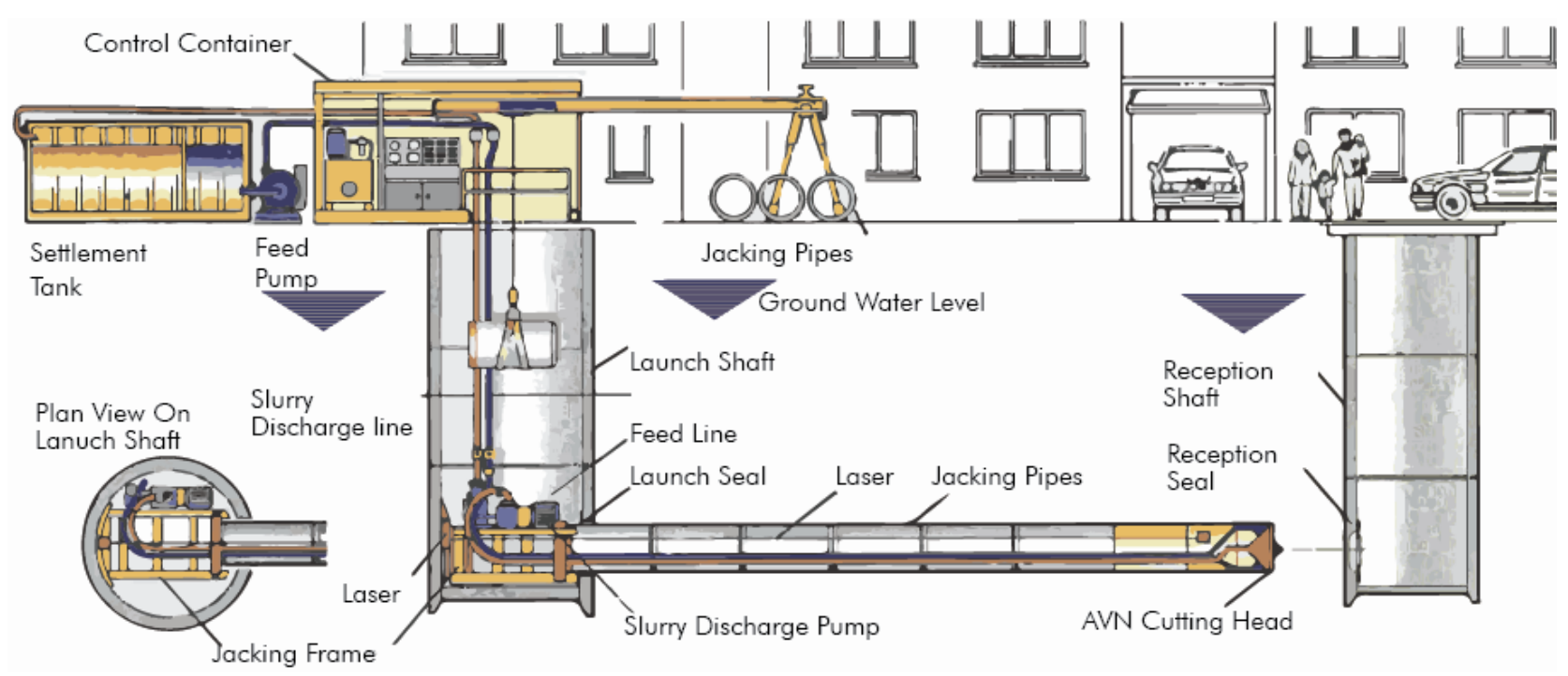

Figure 1: Typical microtunelling installation [15].

the necessary equipment. It also has to offer enough room for the jacked pipes as well as for slurry feed and return. Through the reception shaft, the boring head is taken to the surface. To secure walls of the shafts, they can be made of materials like steel sheet piles or pre-cast reinforced concrete segments using shaft sinking method. In launch shafts, the jacking frame has to be assembled. The jacking pipes for sewage pipelines are most often made of reinforced concrete, polymer concrete, or polyester resins reinforced with glass fibre or stoneware [20].

In trenchless technologies employing the pipe jacking method, pipe joints should transmit longitudinal forces from one pipe to another without damaging it, keep the pipeline tight, and prevent their transverse displacement [14]. In sewage pipelines built using the pipe jacking method, the pipes are butted, without initial gaps, which is a characteristic feature of the technique (Fig. 1).

Manholes located every a few dozen meters, at most up to 100-120 meters, are an indispensable element of each sewage pipeline [14]. Manholes are built in launch shafts and reception shafts, as well as in between them, after completing the pipeline using the pipe jacking method. Manholes and pipes are connected with tight connection bells or proper connectors. The connectors are connected with stub ends, which are permanently assembled with the manhole base. To assemble manholes in large diameter pipelines, holes are made on the side or the top of a pipe. Then, we receive a very long linear object built of butted pipes (without expansion joints), usually of significant rigidity.

In static strength calculations for sewage pipelines built using the pipe jacking method, there are two stages of pipe performance: implementation and operation. At the implementation stage it is necessary to consider the transverse and longitudinal loads acting on pipeline. Longitudinal loads, acting along the pipeline axis, result from the pipe jacking force on the soil and an additional influence of, for example, steering the jacking process [2, $18,20]$. The value of the maximum jacking force $F_{\max }$ can be calculated from the following equation $[8,14]$ :

$$
F_{\text {max }}=\left(\frac{\sigma_{\mathrm{S}}}{\gamma_{\mathrm{b}}} / \frac{\sigma_{\mathrm{m}}}{\sigma_{\mathrm{o}}}\right) A_{\min }
$$

where: $A_{\min }$ - smallest surface transmitting the jacking force, $\sigma_{\mathrm{m}}$ - biggest stress at the edge of a jacking pipe, $\sigma_{\mathrm{o}}$ - evenly distributed stress for axial influence of jacking force, $\sigma_{s}$ - compressive strength of a jacking pipe in the longitudinal direction, $\gamma_{b}-$ safety factor.

The ratio of stresses $\sigma_{\mathrm{m}} / \sigma_{\mathrm{o}}$ is determined based on the knowledge of load eccentricity caused by the jacking force [8] if the resultant force is outside the kernel of a crosssection.

\section{Influence of Mining Soil Deformations on Sewage Pipelines Built With Jacking Method}

To calculate the soil load for sewage pipelines built using the pipe jacking method, Terzaghi's theory and it's modified versions are applied [21]. Vertical soil load 
$p_{v s}$ on the top of pipes is determined with the following dependence $[3,8,17]$ :

$$
p_{v s}=\chi \gamma h
$$

where: $\chi$ - soil arching factor, $\gamma$ - volumetric weight of soil, $h$ - depth of pipe embedding.

Lateral earth pressure $p_{h}$ on a pipe of low deformability is determined with the equation

$$
p_{h}=\chi \gamma h K
$$

where $K$ is earth pressure coefficient.

Transverse influence of mining operations on a pipeline is observed from changes in ground pressure. The changes are caused by horizontal ground strains, characterised by the coefficient $K$, in equation (3). The value of the coefficient significantly changes, which has to be considered in static calculations [10, 13]. For the pipes that can be classified as flexible, additionally, passive earth pressure is considered [14]. The passive ground pressure changes due to the influence of loosening strains $[5,10,13]$. Horizontal strains cause a decrease in the horizontal load on pipes in the loosened soil zone, and an increase in the horizontal load on pipes in the compacted soil zone.

Longitudinal, in relation to the pipeline, horizontal strains in the near-surface soil layer result in longitudinal forces acting on its external surface and longitudinal pipe movements. Figure 2 shows the performance of jacking pipeline joints in mining areas when pipes can freely move in tight connection bells of manholes or where expansion joints are present in the stub ends of manholes. If there are no such expansion joints, the base of a manhole may be damaged, and the displacements of pipes will be smaller.

During horizontal soil loosening, which constitutes the first stage of mining influence on a pipeline, the pipes extend (case 2 in Fig. 2; case 2 in Fig. 3). The extension may be uneven along the considered pipeline section due to random dispersion of the values of deformation indicators. The extreme value $\Delta l_{r \text { max }}$ of the extension for a single joint in a pipe section of length $l$, subjected to the influence of horizontal strains $\varepsilon$, can be written as $\Delta l_{r \max }=\varepsilon l\left[1+n M_{r}(l)\right]$, with probability specified by coefficient of tolerance $n$, where $M_{r}(l)$ is the coefficient of variation of horizontal strains for a section of length $l[4,6,11]$. For example, the value of $\Delta l_{r \text { max }}=38,7 \mathrm{~mm}$ is determined with probability of $0.95(n=1.645$ for normal distribution) for horizontal soil strains of average value $\varepsilon=9.0 \mathrm{~mm}$, pipes of length of $l=2.0 \mathrm{~m}$ and the coefficient of variation of horizontal strains for tension
$M_{r}(l=2 \mathrm{~m})=M_{r}\left(l_{0}\right) \sqrt{l_{0} / l}=0,2 \sqrt{25 / 2}=0.7 \quad[1,10,13]$, where $l_{0}$ is the length of a standard measuring base.

Extension in each pipe joint occurs if the value of tangent forces is greater than resistance forces in a seal in a joint. The force $P_{u}$ necessary to extend a single pipe joint can be determined based on tests conducted for each pipe diameter and type of sealing. The tests can be limited to seals of the same cross-section dimensions, applied for different diameters, but within a specific range (e.g. DN800, DN900, DN1000). Then, it is enough to determine the force per length unit of a seal of a given diameter. The resistance force of a pipe joint when pipes are displaced can be calculated from the equation

$$
P_{u}=\pi D_{k} u
$$

where: $D_{k}$ - diameter at the contact between a seal and sliding element of a joint, $u$ - resistance force of a seal per length unit, determined in tests.

The value of longitudinal axial forces affecting a pipe joint equals the sum of all soil friction forces acting on the external surface of pipes or shear forces in the soil around the surface of pipes [16]. For calculations, a lower value should be assumed, which, for smooth external surface of pipes, represents friction forces. Then, the value of longitudinal axial forces $N_{l}$ acting on a pipe joint in the zone of horizontal soil loosening (tension) equals

$$
N_{l}=l t
$$

where: $l$ - length of considered pipes, $t$ - tangent force for a pipe length unit.

The value of force $t$ can be determined on the basis of tests or, knowing the value of coefficient $\mu$ of soil friction on the external surface of the pipes [2] and the average value of transverse loads on pipes $p_{s r}$, using the equation

$$
t=\pi D_{z} \mu p_{s r}
$$

where $D_{z}$ is the outside diameter of pipes.

The value of longitudinal forces $N_{l}$ depends on the depth of embedding, surcharge loads and soil friction on the external surface of the pipeline. Extensions in all the joints occur if $N_{l}>P_{u}$. If this condition is not met, every second or even third joint may extend, especially if they are short pipes having a smooth outside surface and relatively shallow pipeline embedment. For example, for GRP jacking pipes of nominal diameter DN1100, $u=14.1$ $\mathrm{kN} / \mathrm{m}$ and force $P_{u}=53.1 \mathrm{kN}$ for $D_{k}=1.2 \mathrm{~m}$. In turn, the resultant value of longitudinal axial force $N_{l}=53.1 \mathrm{kN}$ will occur at the depth of approximately $2.0 \mathrm{~m}$ for cohesive 


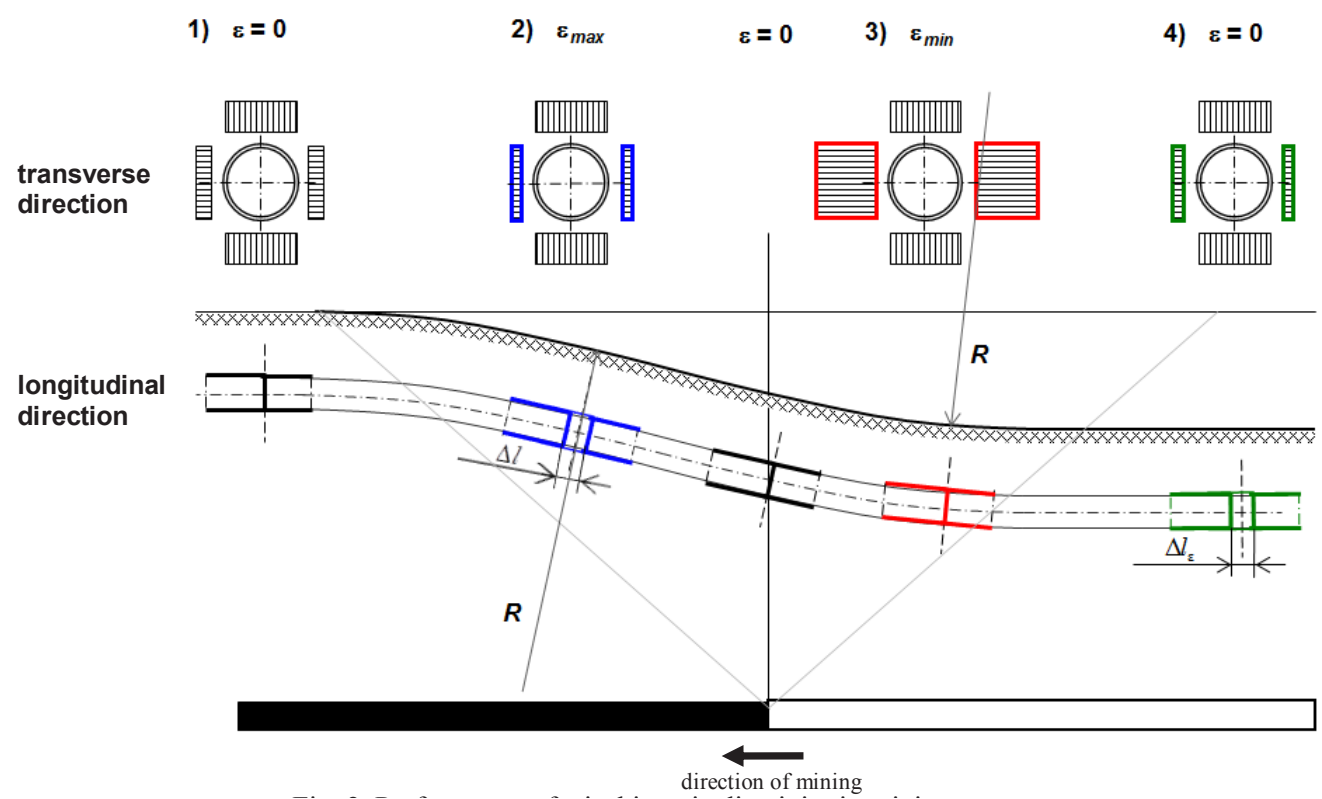

Figure 2: Performance of a jacking pipeline joint in mining areas.

soils of pipe friction coefficient $\mu=0.25$ and approximately $2.5 \mathrm{~m}$ for $\mu=0.20$ (volumetric weight of soil $y=18.5 \mathrm{kN} / \mathrm{m}^{3}$, pipe external diameter $D_{z}=1221 \mathrm{~mm}$ ).

In the second stage of mining influence on a pipeline built using the jacking method, there is horizontal compaction of a soil layer, which results in reducing gaps in the joints that were formed during the first stage (case 3 in Fig. 2; case 3 in Fig. 3). Front surfaces of the pipes return to their initial butted position, and further horizontal soil compaction causes longitudinal compression of the pipes. The maximum value of compressive force $N_{\max }$ should not damage a pipeline, if the pipes can freely slide in tight connection bells of manholes or when there is a proper expansion in joints of stub ends of manholes. The Value of the force does not exceed the maximum jacking force.

After reaching the extreme value of strains for soil compaction, it loosens again, constituting the next, the third stage of mining influence on a pipeline. Then the pipes extend again, which results in expansions in pipe joints (case 4 in Fig. 3). It is the initial state before the influence of further mining operations. Hence, to secure a pipeline built using the pipe jacking method in mining areas, pipe joints should be longer than standard ones, similar to the length of joints of pipes embedded in trenches. Longitudinal, in relation to the pipeline, pipe joints should be able to compensate relative, extreme displacements of the pipes, resulting from horizontal strains of ground $[6,12]$ :

$$
\Delta l_{\varepsilon \max }=2 \varepsilon l[1+n M(l)]
$$

For pipelines of greater diameter, e.g. $D \geq 1 \mathrm{~m}$, surface curvature of radius $R$ should be considered:

$$
\Delta l_{\max }=\Delta l_{\varepsilon \max }+\Delta l_{K_{\text {max }}}=l(2 \varepsilon+D / R)(1+n M(l))
$$

where coefficient of variation $M(l)$ needs to consider random dispersion of surface deformation indicators $\varepsilon$ and $K$ for sections of length $l$, equal to the length of pipes. Pipelines built using the jacking method in mining areas, which will be subjected to the mining influence once, have to remain tight in the expansion joints as shown in case 4 in Fig. 3. Hence, they can be shorter.

Due to horizontal soil loosening and compaction, caused by horizontal strains of ground, distances between manholes along the axis of a pipeline change. Horizontal soil compaction (case 3 in Fig. 3) results in shortening the distances and sliding the ends of pipes into the manholes. It may lead to damaging the base (tight connection bells and inverts), which needs to be considered while designing and assembling sewage pipelines using the pipe jacking method in mining areas. For the manholes with stub ends permanently connected with a base, the joints with pipelines should provide sufficient expansion. The displacements of the pipe ends near manholes are permanent after mining (case 4 in Fig. 3). It also should be considered while designing and building sewage pipelines using the jacking method. The total displacements of the pipe ends near the manholes ( $\Delta L_{1}$ and $\Delta L_{2}$ ) equals the total of gaps in given joints of the section. The maximum value of the total of the displacements can be determined with the following equation: 
1)

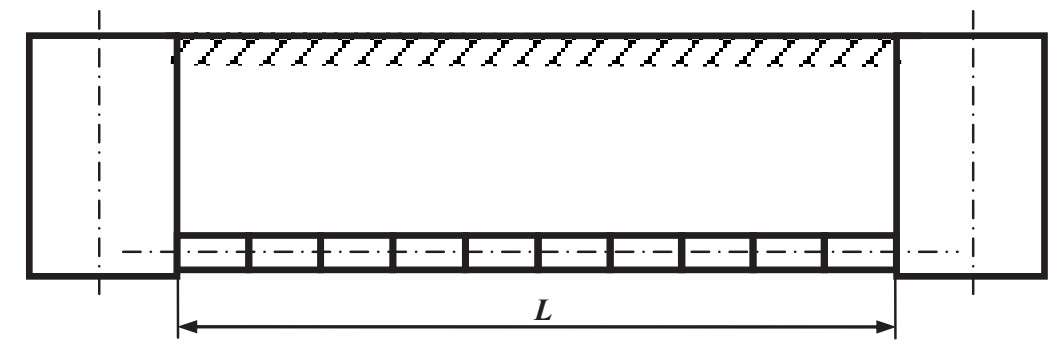

2)

3)
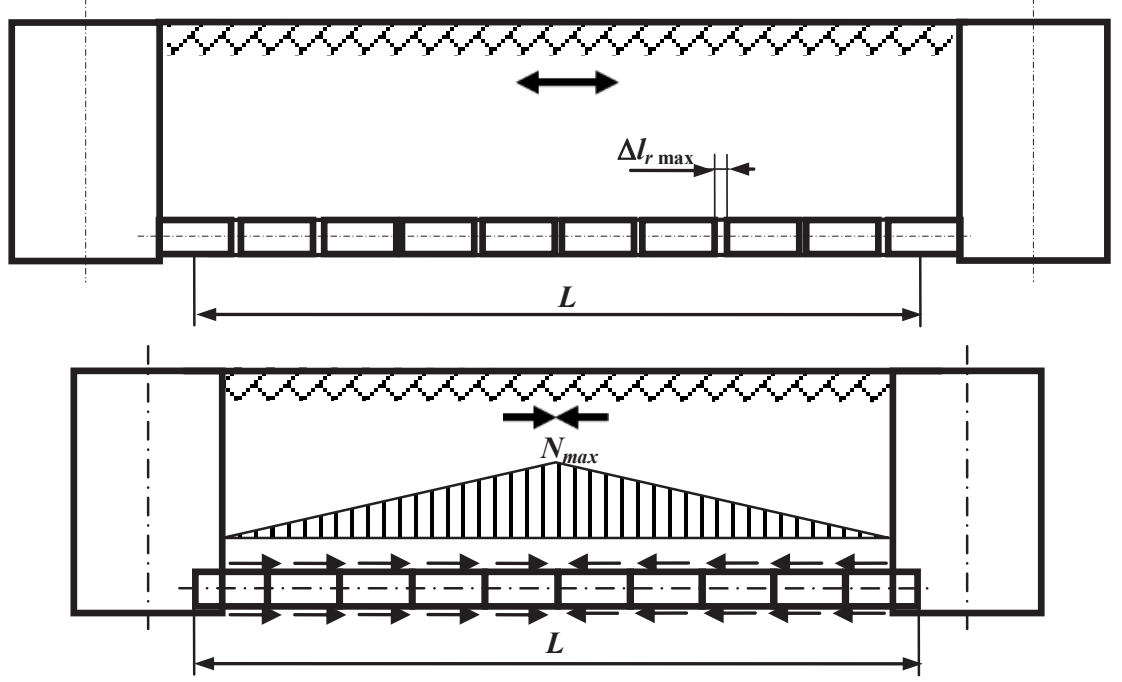

4)

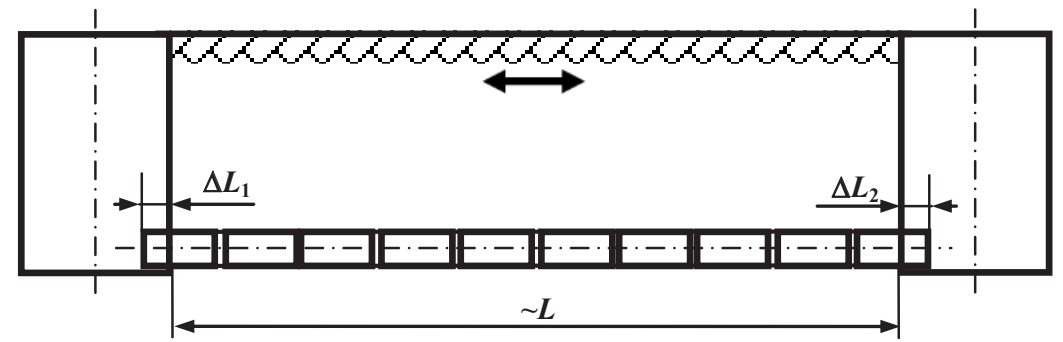

Figure 3: Pipeline section built with the pipe jacking method: 1) initial state, 2) after soil loosening, 3) after soil compaction, 4) pipeline which was subjected to the mining influence once.

$$
\Delta L=\Delta L_{1}+\Delta L_{2}=\varepsilon L\left[1+n M_{z}(L)\right]
$$

where: $L$ - distance between manholes, $n$ - coefficient of tolerance, which depends on the probability that the values of extreme strains are not exceeded, $n=1.645$ for normal distribution and probability $0.95, M_{z}(L)-$ coefficient of variation of strains for soil compaction for length $L$.

The total of displacements $\mathrm{D} L$ of pipe ends into manholes, located approximately 50 metres apart, for average values of horizontal strains of ground of 6.0 $\mathrm{mm} / \mathrm{m}$ and $9.0 \mathrm{~mm} / \mathrm{m}$, will be respectively approximately $0.4 \mathrm{~m}$ and $0.6 \mathrm{~m}$, assuming $M_{z}(L)=0.2$.

Large-diameter sewage pipelines, built with pipe jacking method, can be a long section of pipes assembled without expansion joints, as manholes of a diameter smaller than the diameter of a given pipeline are installed on the side or on the top of pipes. In such cases, it is also necessary to analyse the influence of horizontal soil displacements on the whole pipeline. Hence, a very long linear object, built of butted segments, was considered. It is capable of transmitting significant longitudinal compressive forces and relatively small tensile forces, which depend on the value of resistance force $P_{u}$ in a pipe joint. Longitudinal, in relation to the pipeline, object is subjected to the influence of horizontal soil displacements $u$. The displacements cause longitudinal tangent forces on its external surface. The situation is presented in Fig. 4. 


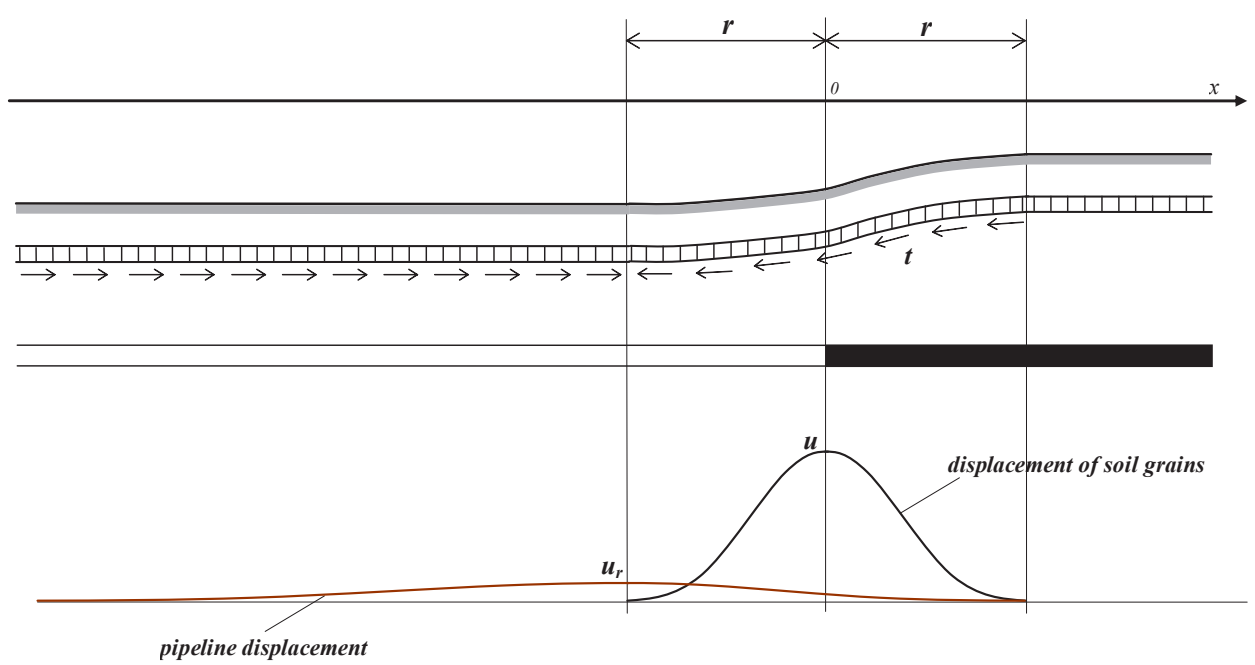

Figure 4: Linear object consisting of butted segments on mining subsoil, $u$ - soil displacement, $u_{r}$ - object displacement.

The value of compressive forces acting on the pipeline within the range of main influences, i.e. along the line segment $[-r ; r]$, will change according to the dependence

$$
N=t(x-r)
$$

where $x$ is the distance from the mining edge, and $r$ is the radius of the range of main influences. The extreme value of compressive axial forces occurs at the distance $-r$ from a mining edge, assuming the boundary value of unit tangent force $t$ on the surface of the whole segment, affected by soil displacement. The value will be

$$
N_{\max }=t(-2 r)
$$

Jacking pipes can adapt to transmit significant longitudinal forces, yet the values of longitudinal axial forces may be much higher than their bearing capacity. A pipeline built using the jacking method of GRP pipes of nominal diameter of $1.1 \mathrm{~m}$, embedded at the depth of 4.0 $\mathrm{m}$, will be subjected to longitudinal force of approximately $42,6 \mathrm{MN}$, once it is within the radius of main influences of $400 \mathrm{~m}\left(\mu=0.25, y=18.5 \mathrm{kN} / \mathrm{m}^{3}\right)$. The value of the force exceeds acceptable value of the jacking force for the pipes of $3.66 \mathrm{MN}$ for the wall thickness of $61 \mathrm{~mm}$.

In mining areas, values of longitudinal forces, acting on the pipelines built using the jacking method without expansion joints, can be much higher than acceptable values of pipe jacking forces. Thus, it is necessary to divide such pipelines into sections and apply proper expansions in joints, calculated with equation (9). The expansions in joints lower the extreme axial forces to the values acceptable for jacking pipes.

\section{Summary}

Pipelines built using the jacking method are linear objects consisting of butted pipe segments. In mining areas, for pipelines built with the pipe jacking method, the longitudinal soil deformations are crucial. It refers mainly to the horizontal strains of ground, and for large-scale pipelines also to the horizontal displacements and subsoil curvature.

In mining areas, due to the influence of horizontal strains and longitudinal soil displacements, it is necessary to apply proper length of pipe joints and proper tight connection bells through the walls of manholes. In large-scale pipelines, expansion joints should be applied, separating segments of acceptable length, due to the bearing capacity of the pipes.

If pipelines built using the pipe jacking method are to be subjected to repetitive mining influences, their joints should have the same capabilities to compensate subsoil deformations as the pipelines embedded in trenches, as they have to interact with deformable subsoil in mining areas. 


\section{References}

[1] Batkiewicz, W. (1971). Odchylenia standardowe poeksploatacyjnych deformacji górotworu (Standard deviations of post-mining deformation of rock mass). (Geodezja $\mathrm{nr} 10$ ). Kraków: Polska Akademia Nauk - Oddziat w Krakowie; Prace Komisji Górniczo-Geodezyjnej.

[2] Cheng W-Ch., Ni J.C., Arulrajah A., Huang H-W. (2018). A simple approach for characterising tunnel bore conditions based upon pipe-jacking data. Tunnelling and Underground Space Technology, 71 (2018), p. 494-504.

[3] Comité français pour les travaux sans tranchées (2006). Microtunnelling and horizontal drilling: French national project microtunnels: recommendations. London: ISTE.

[4] Hejmanowski, R., Popiołek, E., \& Sroka, A. (1994). Probabilistyczna metoda oceny stopnia zagrożenia obiektów na skutek podziemnej eksploatacji górniczej (Probabilistic method to assess risk for construction works caused by underground mining operations). Bezpieczeństwo Pracy $\mathrm{i}$ Ochrona Środowiska w Górnictwie. Kwartalnik WUG. Nr 1/1994, p. 55-60.

[5] Kalisz, P. (2001). Wpływ eksploatacji górniczej na obciążenia poprzeczne rurociąów podziemnych z tworzyw sztucznych (Influence of mining operations on traverse load of underground pipelines made of plastic). Rozprawa doktorska (Doctoral dissertation). Główny Instytut Górnictwa, Katowice.

[6] Kalisz, P. (2005). Probabilistyczna analiza oddziatywania eksploatacji górniczej na rurociagi wykonane metoda przeciskowa (Probabilistic analysis of the influence of mining operations on pipelines built with jacking technique). W Praca zbiorowa pod red. prof. J. Kwiatka pt. Problemy eksploatacji górniczej pod terenami zagospodarowanymi, p. 230-241. Katowice: Gtówny Instytut Górnictwa.

[7] Kędracki, M. (2008). Geotechnika metod bezwykopowych (Geotechnics of trenchless methods). Łódź: Wydawnictwo Politechniki tódzkiej.

[8] Kuliczkowski, A. (2003). Projektowanie konstrukcji przewodów kanalizacyjnych (Designing sewage pipelines). Kielce: Wydawnictwo Politechniki Świętokrzyskiej.

[9] Kuliczkowski, A. (2011). Zalety bezwykopowych technologii budowy i odnowy sieci infrastruktury podziemnej (Advantages of trenchless methods to construct and renovate underground infrastructure). Nowoczesne Budownictwo Inżynieryjne Technologie bezwykopowe.
[10] Kwiatek, J. (1998). Ochrona obiektów budowlanych na terenach górniczych (praca zbiorowa) (Protecting buildings in mining areas). Katowice: Gtówny Instytut Górnictwa.

[11] Kwiatek, J. (2000). Instrukcja nr 12, 1. wyd. Zasady oceny możliwości prowadzenia podziemnej eksploatacji górniczej $z$ uwagi na ochronę obiektów budowlanych (Assessing possibility of mining operations due to protection of construction works). Katowice: Gtówny Instytut Górnictwa.

[12] Kwiatek, J. (2006). Opracowanie probabilistycznej metody oceny skutków podziemnej eksploatacji górniczej w obiektach budowlanych (Developing probabilistic method to asssess consequences of underground mining operations in construction works). Katowice: Główny Instytut Górnictwa.

[13] Kwiatek, J. (2007). Obiekty budowlane na terenach górniczych (Construction works in mining areas). Katowice: Główny Instytut Górnictwa.

[14] Madryas, C., Kolonko, A., \& Wysocki, L. (2002). Konstrukcje przewodów kanalizacyjnych (Construction of sewage pipelines). Wroctaw: Oficyna Wydawnicza Politechniki Wroctawskiej.

[15] Microtunneling Process. (2017). Pobrano 10 październik 2017, z https://www.alnubla.net/microtunneling-process (10 October 2017, retrieved from https://www.alnubla.net/microtunnelingprocess).

[16] Mokrosz, R. (1985). Wprowadzenie do mechaniki budowli liniowych zagtębionych w gruncie na terenach górniczych (Introduction to mechanics of linear buildings embedded into the soil in mining areas). Warszawa: Wydawnictwo Ossolineum.

[17] Najafi, M. (2010). Trenchless Technology Piping. New York, USA: McGraw-Hill Professional Publishing.

[18] Pellet-Beaucour A.-L., Kastner R. (2002): Experimental and analytical study of friction forces during microtunneling operations. Tunnelling and Underground Space Technology, 17 (2002), p. 83-97.

[19] Thomson, J. C. (2004). Pipejacking and microtunnelling. London: Spon Press.

[20] Westfall D. E., Boyce G. M. (1996). Small-Diameter Tunnels. Tunnel Engineering Handbook, p. 311-319, Chapman \& Hall.

[21] Zhang H., Zhang P., Zhou W., Dong S., Ma B. (2016). A new model to predict soil pressure acting on deep burial jacked pipes. Tunnelling and Underground Space Technology, 60 (2016), p. 183-196. 